\title{
Corrosion Inhibition of Carbon Steel Using Palm Oil Leaves Extract
}

\author{
Nor Insyirah Hairul Salleh and Arman Abdullah ${ }^{*}$ \\ Faculty of Chemical \& Natural Resources Engineering, University Malaysia Pahang, 26300 Gambang, Pahang, Malaysia
}

\author{
* Corresponding author: \\ email: armanabdullah@ump.edu.my
}

Received: October 16, 2018

Accepted: November 14, 2018

DOI: $10.22146 /$ ijc.39707

\begin{abstract}
Palm oil (Elaeis guineensis) leaves extract was investigated on its potential to inhibit carbon steel corrosion via weight loss and potentiodynamic polarization methods. Corrosion inhibition of carbon steel using palm oil leaves extract was determined at various temperatures, salinities, and concentrations. The inhibition efficiency increased with the increasing of inhibitor concentration but decreased with the rise in temperature. The highest inhibitor efficiency was $83.70 \%$ with a corrosion rate of $0.44 \mathrm{~mm} / \mathrm{yr}$ which was obtained at zero salinity (in distilled water) with $25 \%$ of inhibitor concentration at $303 \mathrm{~K}$. The results obtained proved that the extract solution from palm oil leaves can be used as an effective inhibitor of carbon steel in seawater.
\end{abstract}

Keywords: green inhibitor; palm oil leaves extract; potentiodynamic polarization methods; carbon steel

\section{- INTRODUCTION}

Carbon steel has been extensively used in a wide range of industrial applications for different purposes under different conditions due to its low cost and availability. For example, in the oil and gas industry, carbon steel pipelines are normally used in transporting the fluid hydrocarbons. These carbon steel pipelines are exposed to various environments including the corrosive seawater. Corrosion control is very important in protecting carbon steel against corrosion. The inhibitor is one of the effective methods to prevent corrosion [1]. Typically, carbon steel has a high carbon content of about $0.2-2.1 \%$, manganese (1.65\%), copper $(0.6 \%)$, and silicon (0.6\%) This properties and characteristics make carbon steel to be ductile, tough, and malleable. It has good tensile strength but poor resistance to corrosion [2].

The application of a corrosion inhibitor is conducted by adding in a very low concentration of inhibitor to treat the surface of the metal that exposed to the environment [3]. Most of the current synthetic compounds are good anticorrosive; however, contain a high level of toxicity and exhibit hazardous effects on the environment [4]. It leads to many studies on green inhibitor, but most of them using expensive sources such as ginger extract, seaweed extract, and natural honey.
As to focus on the need to develop a new type of green inhibitor which is nontoxic and cheap, palm oil is one of the potential natural products which is nontoxic, abundant, and environmentally friendly [5-7]. Previously, Abboud et al. [8] studied the effect of pomegranate leaves extract on carbon steel in hydrochloric acid using the weight loss method, potentiodynamic polarisation, and surface analysis. Vidhya and Rose [9] also investigated Solanum nigrum leaves as a corrosion inhibitor. Therefore, this study investigated the effect of palm oil leaves extract as a corrosion inhibitor on carbon steel in seawater via weight loss method and potentiodynamic polarisation on the basis of temperature, salinity, and concentration of inhibitor.

\section{- EXPERIMENTAL SECTION}

\section{Experimental Materials Preparation}

\section{Metal coupon}

The carbon steel specimens were cut into $2.6 \times 1.8$ $\times 0.7 \mathrm{~cm}$ for weight loss method and $1.8 \times 0.7 \mathrm{~cm}$ for potentiodynamic polarisation measurement. The carbon steel specimens were cleaned, scrubbed, and polished with sandpapers grade 400 and 600 . Then the specimens were degreased with acetone and rinsed with distilled water, dried, stored in desiccators and reweighed [8]. For polarisation measurement, the carbon 
steel specimens were connected to a copper wire and embedded in epoxy resin. As for the weight loss measurement, the samples were fully immersed in the test media at a different concentration of inhibitor.

\section{Palm oil leaves extract solution}

Fresh palm oil leaves were cut into small pieces, cleaned with distilled water, and dried in an oven at $100^{\circ} \mathrm{C}$ for $24 \mathrm{~h}$. After drying, the leaves were ground in a mixer. Fifty grams of palm oil leaves powder were dissolved in $500 \mathrm{~mL}$ of methanol. The mixture was stirred for $12 \mathrm{~h}$ and subsequently filtered to collect the crude extract.

\section{Test media}

The experiment was performed in a high salinity medium using seawater. The seawater was collected at Pantai Balok, Kuantan Pahang. For weight loss experiment, seawater with different concentrations of palm oil extract solution was prepared as stock solutions.

For the test solution, palm oil leaves extracts were prepared in the concentrations of $0,5,10,15,20$ and $25 \%$ $(\mathrm{v} / \mathrm{v})$ from the stock solution. For the weight loss method, $25 \mathrm{~mL}$ of palm oil leaves extract was mixed with $200 \mathrm{~mL}$ of seawater.

\section{Instrumentation and Calculation Methods}

\section{Potentiodynamic polarization}

The electrochemical study was carried out using a potentiostat and connected to a computer for data analysis. The experiments were performed using a cell with a three-electrode system consisting of a platinum electrode as the reference electrode and carbon steel as the working electrode and counter electrode [10].

The material used for constructing the working electrode was the same used for gravimetric measurement. The surface area exposed to the electrolyte is $0.056 \mathrm{~cm}^{2}$. Potentiodynamic polarisation curves were plotted at a polarisation scan rate of $1.6 \mathrm{mV} / \mathrm{s}$. To investigate the effects of temperature and immersion time on the inhibitor performance, the tests were carried out in at 303 and $333 \mathrm{~K}$. The experiments were conducted at different inhibitor concentrations of palm oil leaves extract.

\section{Weight loss method}

The carbon steel coupon of $2.6 \times 1.8 \times 0.7 \mathrm{~cm}$ was used for weight loss measurement. The coupon was weighed accurately and subsequently immersed in a beaker that contained the test media. After 7 and 14 days of immersion, the coupons were taken out, washed with a soft brush under running water to remove the corrosion product, dried, and weighed accurately [8]. The solution without inhibitor was used as the control experiment.

The plots of average weight loss and its corresponding calculated corrosion rate versus exposure time were plotted. The corrosion rate (CR) was calculated for 14 days at each inhibitor concentration using the following equation:

$\mathrm{CR}(\mathrm{mm} /$ year $)=\frac{87.6 \mathrm{~W}}{\rho \mathrm{At}}$

where $\mathrm{W}$ is the weight loss (mg), $\rho$ is the density of carbon steel $\left(\mathrm{g} / \mathrm{cm}^{3}\right), A$ is the surface area of the sheet $\left(\mathrm{cm}^{2}\right)$, and $t$ is corrosion reaction period.

\section{Inhibition efficiency}

The Inhibition Efficiency (IE) was determined using electrochemical measurement and weight loss method, and it was calculated using the following equation:

$\mathrm{IE} \%=\left[\frac{\mathrm{CR}_{\mathrm{wi}}-\mathrm{CR}_{\mathrm{i}}}{\mathrm{CR}_{\mathrm{wi}}}\right] \times 100$

where $\mathrm{CR}_{\mathrm{i}}$ is the corrosion rate with inhibitor and $\mathrm{CR}_{\mathrm{wi}}$ is the corrosion rate without inhibitor.

\section{Isotherm adsorption calculation}

Isotherm adsorption provides basic information about the interaction between the inhibitor and the carbon steel surface [10]. On shielded metal surfaces, a thin layer is formed called surface coverage $(\theta)$. It has a correlation with inhibition efficiency as follows: $\mathrm{IE} \%=\theta \times 100 \%$

It is determined at different inhibitor concentrations using Langmuir adsorption isotherm, and it can be expressed as:

$\frac{\mathrm{C}_{\text {in }}}{\theta}=\frac{1}{\mathrm{~K}}+\mathrm{C}_{\text {in }}$ 
Here, $\mathrm{K}$ is the equilibrium constant of adsorption and $\mathrm{C}_{\text {in }}$ is the inhibition concentration. Many previous researchers have explained the Langmuir adsorption isotherm for the interaction of adsorbed species on the metallic surfaces [11-12].

\section{- RESULTS AND DISCUSSION}

Experiments were conducted at standard room temperature with different inhibitor concentrations to study the corrosion rate in seawater. The corrosion rate was determined by using the weight loss method after 14 days of immersion. Table 1 presents the results obtained for the weight loss experiments.

The results obtained show that as the concentration of palm oil leaves extract was increased, the rate of corrosion decreased and the inhibitor efficiency increased. The highest inhibition efficiency of $83.67 \%$ was achieved when $25 \%(\mathrm{v} / \mathrm{v})$ of palm oil leaves extract was used. From the data gained, the inhibitor showed an excellent result for inhibiting the corrosion of carbon steel in seawater.

\section{Isotherm Adsorption}

The Langmuir adsorption isotherm was drawn by plotting versus, considering the values from weight loss method at room temperature for carbon steel in seawater at a different concentration of inhibitors, and the graph is shown in Fig. 1. The straight line with a good $\mathrm{R}^{2}$ value shows that the palm oil leaves extract as inhibitor obeys the Langmuir adsorption isotherm. It can be concluded that the palm oil leaves extract can act as an inhibitor.

\section{Polarization Curve}

Fig. 2 and 3 show the potentiodynamic curves of carbon steel in distilled water and seawater in the absence and presence of palm oil leaves extract as inhibitor with two different concentrations at $333 \mathrm{~K}$. The electrochemical parameters of corrosion potential $\left(\mathrm{E}_{\text {corr }}\right)$, corrosion current density $\left(\mathrm{j}_{\text {corr }}\right)$, anodic $\left(\beta_{\mathrm{a}}\right)$ and cathodic $\left(\beta_{\mathrm{c}}\right)$ Tafel constants, corrosion rate (CR), and inhibitor efficiency (IE) shown in Table 2 were collected from the Tafel plots.

Table 1. Effects of inhibitor concentration on the corrosion rate of carbon steel

\begin{tabular}{cccc}
\hline $\begin{array}{c}\text { Extract Inhibitor } \\
\text { concentration (\%) }\end{array}$ & $\begin{array}{c}\text { Corrosion rate } \\
\text { CR }(\mathrm{mm} / \mathrm{yr})\end{array}$ & $\begin{array}{c}\text { Inhibitor efficiency } \\
\text { (\% IE) }\end{array}$ & $\begin{array}{c}\text { Average weight loss } \\
(\mathrm{g})\end{array}$ \\
\hline 0 & 0.9302 & control & 0.10475 \\
5 & 0.6896 & 25.86 & 0.07765 \\
10 & 0.5977 & 35.75 & 0.06730 \\
15 & 0.4427 & 52.41 & 0.04985 \\
20 & 0.1929 & 79.26 & 0.02172 \\
25 & 0.1519 & 83.67 & 0.01710 \\
\hline
\end{tabular}

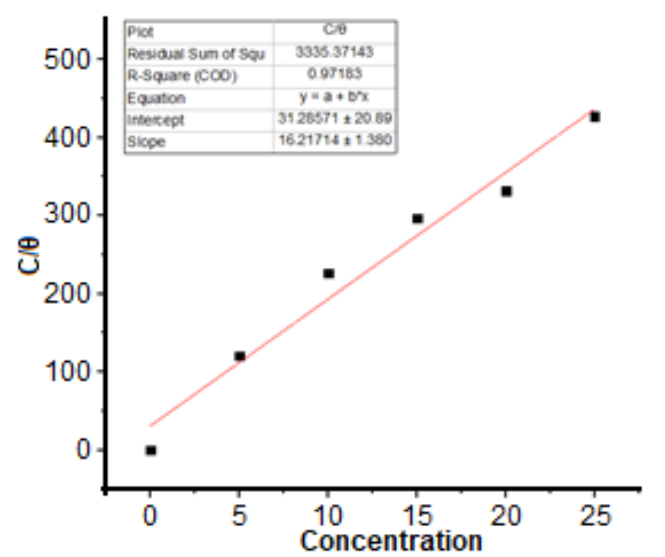

Fig 1. Langmuir isotherm for palm oil leaves extract adsorption on carbon steel

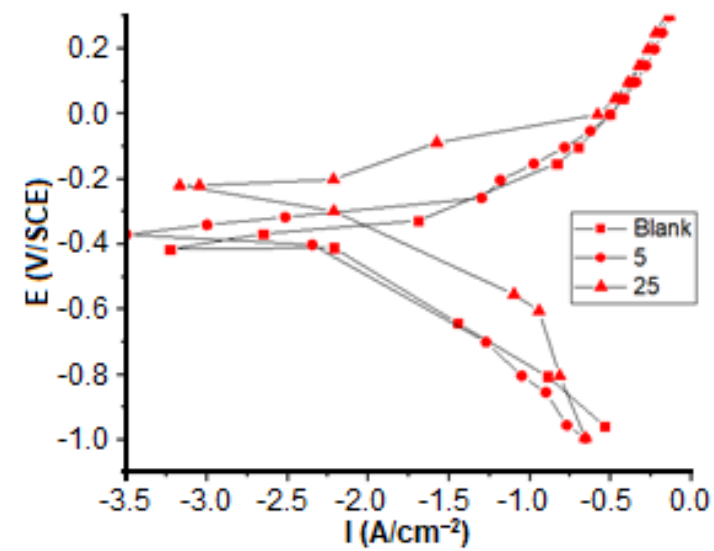

Fig 2. Potentiodynamic curve of carbon steel in distilled water at $303 \mathrm{~K}$ 
The calculated inhibition efficiency based on corrosion current density values is obtained from Table 2 . In distilled water at $303 \mathrm{~K}$, the inhibitor efficiency was $61.85 \%$ for $5 \%$ inhibitor and $83.70 \%$ in $25 \%$ inhibitor. At $333 \mathrm{~K}$, the inhibitor efficiency was $4.98 \%$ at $5 \%$ inhibitor and $33.18 \%$ at $25 \%$ inhibitor. On the other hand, in seawater, at $303 \mathrm{~K}$, the inhibitor efficiency was $64.43 \%$ and $78.90 \%$ for $5 \%$ inhibitor and $25 \%$ inhibitor respectively. As for $333 \mathrm{~K}$, the inhibitor efficiency was $45.68 \%$ and $45.74 \%$ for $5 \%$ and $25 \%$ inhibitor respectively. It is clearly shown that as inhibitor increase, the inhibitor efficiency also increases.

The cathodic Tafel slopes $\left(\beta_{c}\right)$ did not change significantly with the addition of the inhibitors showing that the adsorbed inhibitor molecules did not affect the hydrogen evolution reaction. The same observation was found in the samples using seawater. The anodic Tafel slopes $\left(\beta_{\mathrm{a}}\right)$ also did not change significantly with the addition of the inhibitors which shows that the extract can reduce the metal dissolution process. Table 2 also shows that the corrosion current density significantly decreased with the addition of the inhibitor at all tested temperatures. The inhibitory efficiency of palm oil leaves extract reached up to $83 \%$ at $303 \mathrm{~K}$ and $33.18 \%$ at $333 \mathrm{~K}$ in distilled water.

\section{Effect of Temperature}

The effect of temperature on the inhibition performances of palm oil leaves extract was investigated via a potentiodynamic polarization graph at $303 \mathrm{~K}$ and $333 \mathrm{~K}$ with different concentration of corrosion inhibitor. It is shown that the corrosion current densities increase with temperature even though it is at distilled water or seawater and the corrosion inhibitor concentration. At $303 \mathrm{~K}$ with an inhibitor concentration of $5 \%$ by volume in distilled water and seawater, the inhibitor efficiency is $61.85 \%$ and $64.43 \%$ respectively. It shows a better inhibitor efficiency compare to the inhibitor efficiency at $333 \mathrm{~K}$ which have $4.98 \%$ in distilled water and $45.68 \%$ in seawater. This is same goes to the inhibitor efficiency with an inhibitor concentration of $25 \%$ by volume which shows higher IE\% at $303 \mathrm{~K}(83.70 \%$ in distilled water and
$78.98 \%$ in seawater) as compared to $333 \mathrm{~K}(33.18 \%$ in distilled water and $45.74 \%$ in seawater).

The corrosion current densities in the absence and presence of both inhibitors increased with the increasing the temperature. A similar observation was reported elsewhere in the literature [13]. Such results show that the rate of corrosion of carbon steel enhanced with the increasing the temperature. The inhibition efficiencies were calculated at different temperatures. The rate of corrosion increased at a higher temperature in seawater and distilled water. The inhibition efficiency at a higher temperature also smaller than that at room temperature [14-18].

\section{Effect of Salinity}

The effect of salinity on the corrosion of carbon steel in the absence and presence of inhibitors was studied, and the electrochemical kinetic parameters are tabulated in Table 2 . Seawater has a higher salinity than distilled water. The corrosion rate of carbon steel in seawater was higher than that in distilled water at room temperature. The inhibition efficiency increased more in seawater rather than in distilled water as the corrosion rate in seawater was higher than distilled water.

\section{Effect of Inhibitor Concentration}

In the absence of inhibitor, the carbon steel corrosion in seawater is generally characterized by simple metal dissolution followed by pitting. For this study, three concentrations used were 0,5 , and $25 \%$. The

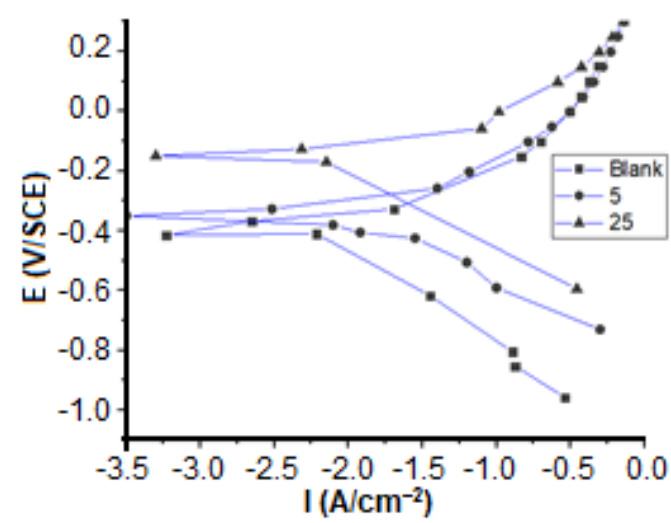

Fig 3. Potentiodynamic curve of carbon steel in seawater at $303 \mathrm{~K}$ 
Table 2. The kinetic parameters obtained from Tafel extrapolation carbon steel at 303 and $333 \mathrm{~K}$ in seawater and distilled water with $5 \%$ and $25 \%(\mathrm{v} / \mathrm{v})$ of palm oil leaves extract

\begin{tabular}{|c|c|c|c|c|c|c|c|}
\hline & Temperature & Inhibitor \% & $\mathrm{j}_{\text {corr }}$ & $\beta_{\alpha}$ & $-\beta_{c}$ & CR & IE\% \\
\hline \multirow{6}{*}{$\begin{array}{l}\text { Distilled } \\
\text { water }\end{array}$} & \multirow{3}{*}{$303 \mathrm{~K}$} & 0 & 0.31 & 61 & 90 & 2.70 & 0.00 \\
\hline & & 5 & 0.12 & 108 & 113 & 1.30 & 61.85 \\
\hline & & 25 & 0.05 & 86 & 102 & 0.44 & 83.70 \\
\hline & \multirow{3}{*}{$333 \mathrm{~K}$} & 0 & 0.53 & 333 & 112 & 4.62 & 0.00 \\
\hline & & 5 & 0.49 & 345 & 97 & 4.39 & 4.98 \\
\hline & & 25 & 0.34 & 436 & 118 & 3.03 & 33.18 \\
\hline \multirow{6}{*}{ Seawater } & \multirow{3}{*}{$303 \mathrm{~K}$} & 0 & 0.18 & 298 & 213 & 1.57 & 0.00 \\
\hline & & 5 & 0.06 & 206 & 186 & 0.56 & 64.43 \\
\hline & & 25 & 0.03 & 271 & 210 & 0.33 & 78.98 \\
\hline & \multirow{3}{*}{$333 \mathrm{~K}$} & 0 & 0.72 & 135 & 131 & 6.28 & 0.00 \\
\hline & & 5 & 0.37 & 170 & 61 & 3.26 & 45.68 \\
\hline & & 25 & 0.39 & 227 & 224 & 3.40 & 45.74 \\
\hline
\end{tabular}

inhibitor concentrations were calculated in percentage by weight. Based on the results of the experiment, the higher the concentration, the higher the rate of corrosion and percentage of inhibition efficiency. A similar result was reported where the inhibition efficiency increased with the increasing extract concentration while the corrosion rate decreased [19]. This is due to the adsorption of inhibitor onto the metal surface thus producing a barrier film and consequently minimizing the anodic metal dissolution and cathodic hydrogen evolution.

\section{- CONCLUSION}

In this study, it can be concluded that the inhibition efficiency and corrosion rate depend on the inhibitor concentration. The results show that the palm oil leaves exhibited an excellent performance (more than $80 \%$ ) against the corrosion of carbon steel in distilled water and seawater. The efficiencies were determined to be $83.67 \%$ via weight loss method and $83.70 \%$ via polarisation method. Via polarisation study, the inhibition efficiency increased when the inhibitor concentration was increased but decreased when the temperature was increased. It shows that both of the methods can be used and produced accurate results. The results obtained from polarisation and weight loss methods are in good agreement.

\section{- ACKNOWLEDGMENTS}

The deepest appreciation goes to University Malaysia
Pahang (UMP) for funding this research with the grant reference no RDU1703185.

\section{- REFERENCES}

[1] Bouklah, M., Hammouti, B., Benkaddour, M., and Benhadda, T., 2005, Thiophene derivatives as effective inhibitors for the corrosion of steel in 0.5 $\mathrm{M} \mathrm{H}_{2} \mathrm{SO}_{4}$, J. Appl. Electrochem., 35(11), 1095-1101.

[2] Chuka, C.E., Odio, B.O., Chukwuneke, J.L., and Sinebe, J.E., 2014, Investigation of the effect of corrosion on mild steel in five different environments, IJSTR, 3 (7), 306-310.

[3] Kesavan, D., Gopiraman, M., and Soluchana, N., 2012, Green inhibitor for corrosion of metals: A review, Chem. Sci. Rev. Lett., 1 (1), 1-8.

[4] Fouda, A.S., Al-Sarawy, A.A., and El-Katori, E.E., 2006, Pyrazolone derivatives as corrosion inhibitors for C-steel $\mathrm{HCl}$ solution, Desalination, 201 (1-3), 113.

[5] Roberge, P.R., 2000. Handbook of Corrosion Engineering, McGraw Hill, New York, USA.

[6] Sastri, V.S., 2011, Green Corrosion Inhibitors: Theory and Practice, John Wiley \& Sons, Inc., New York, USA.

[7] Ostovari, A., Hoseinieh, S.M., Peikari, M., Shahizadeh, S.R., and Hashemi S.J., 2009, Corrosion inhibition of mild steel in $1 \mathrm{M} \mathrm{HCL}$ solution by henna extract: A comparative study of 
the inhibition by henna and its constituents (lawsone, gallic acid, $\alpha$-D-glucose and tannic acid), Corros. Sci., 51 (9), 1935-1949.

[8] Abboud, Y., Tanane, O., El-Bouari, A., Salghi, R., Hammouti, B., Chetouani, A., and Jodeh, S., 2016, Corrosion inhibiton of carbon steel in hydrochloric acid solution using pomegranate leave extracts, Corros. Eng. Sci. Technol., 5 (8), 557-565.

[9] Vidhya, S., and Rose, A.L., 2002, Evaluation of Solanum nigrum leaves extract as corrosion inhibitor and reductant for the green synthesis of gold nanoparticles, Int. J. Res. Dev. Pharm. Life Sci., 3 (3), 1011-1021.

[10] Pradityana, A, Sulistijono, Shahab, A, Noerochim, L., and Susanti, D., 2016, Inhibition of corrosion of carbon steel in $3.5 \% \mathrm{NaCl}$ solution by Myrmecodia pendans extract, Int. J. Corros., 2016, 6058286.

[11] Gerengi, H., and Sahin, H.I., 2012, Schinopsis lorentzii extract as a green corrosion inhibitor for low carbon steel in $1 \mathrm{M} \mathrm{HCl}$, Ind. Eng. Chem. Res., 51 (2), 780-787.

[12] Bayol, E., Kayakirilmaz, K., and Erbil, M., 2007, The inhibitive effect of hexamethylenetetramine on the acid corrosion of steel, Mater. Chem. Phys., 104 (1), 74-82.

[13] Tang, L., Mu, G., and Liu, G., 2003, The effect of neutral red on the corrosion inhibition of cold rolled steel in $1 \mathrm{M} \mathrm{HCl}$ acid, Corros. Sci., 45 (10), 22512262.

[14] Dariva, C.G., and Galio, A.F., 2014, "Corrossion Inhibitor - Principles, Mechanism, and Application" in Developments in Corrosion Protection, Ed., Aliofkhazraei, M., $1^{\text {st }}$ ed., Intech Open, London, UK, 365-380.

[15] El-Etre, A.Y., and Abdallah, M., 2000, Natural honey as corrosion inhibitor for metals and Alloys. II. C-steel in high saline water, Corros. Sci., 42 (4), 731-738.

[16] Chigondo, M., and Chigondo, F., 2016, Recent natural corrosion inhibitors for mild steel: An overview, J. Chem., 2016, 6208937.

[17] Fiori-Bimbi, M.V., Alvarez, P.E., Vaca, H., and Gervasi, C.A., 2015, Corrosion inhibition of mild steel in $\mathrm{HCl}$ solution by pectin, Corros. Sci., 92, 192199.

[18] Vasudha, V.G., and Priya, K.S., 2014, Corrosion inhibition of mild steel in $\mathrm{H}_{2} \mathrm{SO}_{4}$ media using Polyalthia longifolia leaves, Chem. Sci. Rev. Lett., 2 (6), 435-443.

[19] Anbasari, K., and Vasudha, V.G., 2014, Corrosion inhibition potential of Curcubita maxima plant extract on mild steel in acid media, Chem. Sci. Rev. Lett., 3 (9), 45-51. 